\title{
Rancang Bangun Sistem Informasi Akademi: Modul Sistem Absensi Berbasis Mobile dan Web pada Universitas Universal
}

\author{
Johanes Try Oktavianus Gulo ${ }^{1}$, Eka Lia Febrianti ${ }^{2}$, Holong Marisi Simalango ${ }^{3}$ \\ 1,2,3 Teknik Perangkat Lunak, Universitas Universal, Kompleks Maha Vihara Duta Maitreya, Kota Batam, \\ Kepulauan Riau, Indonesia, 29444 \\ e-mail: 1johangulo.jg@gmail.com, ${ }^{2}$ ekalia88@gmail.com, ${ }^{3}$ simalangoholong@ gmail.com
}

Submitted Date: September 02 $2^{\text {nd }}, 2020$

Revised Date: September 22nd, 2020
Reviewed Date: September $21^{\text {st }}, 2020$

Accepted Date: September $30^{\text {th }}, 2020$

\begin{abstract}
The academic information system that focuses on the attendance module is a continuation of the manual attendance that imposes the use of attendance papers that are paraphrased by students. Attendance modules at Universal University can be designed utilizing Internet technology and network, where students only use smartphones to scan Quick-Response Code (QR Code) and web-based applications for lecturers to verify attendance. The attendance module is designed using real-time data processing. The software process Model used is the waterfall model and assisted with analysis using Unified Modelling Language (UML). The design of the application uses the PHP programming language for Web applications and Java for mobile applications, as well as databases using MySQL. The result of the design of the build attendance module in the form of a mobile application for use by students who can scan QR Code as attendance, and a Web application to be used by the lecturer as an attendance verification that has scanned QR Code and students who are not present. Attendance is more effective online when compared to manual attendance.
\end{abstract}

Keywords: Information Systems; Attendance; QR Code

\begin{abstract}
Abstrak
Sistem Informasi Akademi yang berfokus pada modul absensi merupakan kelanjutan dari absensi manual yang memberlakukan penggunaan kertas absensi yang diparaf oleh mahasiswa. Modul absensi di Universitas Universal dapat dirancang memanfaatkan teknologi dan jaringan internet, dimana mahasiswa hanya menggunakan smartphone untuk scan Quick-Response Code (QR Code) dan aplikasi berbasis web untuk dosen memverifikasi absensi. Modul absensi dirancang menggunakan real time untuk pengolahan data. Model proses perangkat lunak yang digunakan dalam pengembangan perangkat lunak yaitu model waterfall dan dibantu dengan analisis menggunakan Unified Modelling Language (UML). Implementasi aplikasi menggunakan bahasa pemrograman Hypertext Prepocessor (PHP) untuk aplikasi web dan Java untuk aplikasi mobile, serta database menggunakan MySQL. Hasil dari perancangan bangun modul absensi berupa aplikasi mobile untuk digunakan oleh mahasiswa yang bisa scan QR Code sebagai absensi, dan aplikasi web untuk digunakan oleh dosen sebagai verifikasi absensi yang telah scan QR Code serta mahasiswa yang tidak hadir. Absensi online lebih efektif bila dibandingkan dengan absensi.
\end{abstract}

Keywords: Sistem Informasi; Absensi; QR Code

\section{Pendahuluan}

Sistem Informasi Akademi merupakan perangkat lunak induk yang akan mengelola adminsitrasi mahasiswa, dosen, staf, dan petinggi di Universitas Universal. Pada saat ini, Sistem Informasi Akademi Universitas Universal baru memulai untuk pembangunan sistem yang di antaranya telah dibagi beberapa modul. Modul absensi merupakan bagian dari sistem informasi akademi berfungsi untuk mendokumentasikan seluruh catatan kehadiran setiap mahasiswa di Perguruan Tinggi. Presentase untuk kehadiran mahasiswa pada setiap perkuliahan merupakan 
salah satu sebagai syarat lulus setiap mata kuliah yang diambil.

Prosedur absensi mahasiswa masih dilakukan secara manual, yaitu menggunakan kertas untuk mencatat kehadiran mahasiswa di kelas di Universitas Universal di Kota Batam. Absensi secara manual memiliki masalah yaitu perhitungan kompensasi ketidakhadiran yang tidak secara real-time dicatat sehingga terlambatnya pemberitahuan ketidakhadiran yang sudah melampaui batas membuat mahasiswa tidak dapat mengikuti ujian akhir semester. Permasalahan ini melatarbelakangi kebutuhan terhadap sebuah aplikasi absensi yang dapat mengelola data secara real-time, efesiensi waktu absensi, serta menghilangkan penggunaan kertas.

Penelitian yang dilakukan oleh Zebua \& Pritiwanto pada tahun 2017 tentang Pembangunan Mobile Web Absensi Mahasiswa Pada Platform Android Yang Terintegrasi Dengan Website Utama Sistem Informasi Akademik (SIA) STMIK Budi Darma. Penelitian ini menjelaskan tentang pembangunan dan dengan pemanfaatan mobile web absensi mahasiswa untuk mempermudah rekapitulasi serta memvalidasi nilai akhir kehadiran mahasiswa. Kesimpulan dari hasil penelitian adalah pembangunan aplikasi absensi yang dapat mengelola data secara otomatis namun pengambilan absensi masih dilakukan oleh dosen sehingga memerlukan waktu lebih banyak jika berada dikelas yang besar (Zebua \& Pritiwanto, 2017).

Penelitian lain yang telah dilakukan oleh Danur C et al., pada tahun 2016 tentang Rancang Bangun Aplikasi Absensi Mahasiswa pada Platform Android. Penelitian ini menguraikan tentang pembangunan aplikasi absensi berbasis mobile untuk mengatasi permasalahan tentang pengolahan data absensi serta mempermudah dalam proses absensi mahasiswa. Aplikasi absensi yang berjalan pada platform android yang mana telah umum digunakan memudahkan user dalam menggunakan aplikasi absensi (Onny, Danur, Piarsa, \& Sudana, 2016).

Penelitian yang dilakukan oleh Nalintipwong et al., tentang penerapan QR Code untuk merekam kehadiran kelas. Penelitian ini membahas tentang pemanfaatan fitur QR Code untuk melakukan perekaman kehadiran siswa dikelas. Hasil penelitian menunjukkan perbandingan selisih waktu yang diperlukan untuk merekam kehadiran siswa menggunakan fitur QR Code dan absensi manual.
Sistem absensi yang dibagun akan berjalan secara web based dan mobile based pada penelitian Nalintipwong et al., pada tahun 2019. Pada web based akan terjadi proses pengolahan data absensi, rekapitulasi data hasil olahan, dan generate QR Code untuk setiap mata kuliah. Proses pada mobile based yaitu Scan QR Code untuk merekam kehadiran mahasiswa. Cara kerja absensi yaitu mahasiswa akan melakukan scanning QR Code mata kuliah yang sedang berlangsung untuk merekam kehadiran. Proses absensi menggunakan metode ini memperkecil waktu absensi mahasiswa sehingga tidak menggangu waktu pembelajaran di kelas (Nalintipwong, dkk, 2019).

Pada penjelasan ketiga penelitian yang dijadikan sebagai referensi, penulis mengusulkan dalam melakukan rancang bangun perangkat lunak absensi perkuliahan berbasis web based dengan memanfaatkan fitur Quick-Response Code (QR Code) pada aplikasi mobile. Pemanfaatan fitur QR Code sangat membantu dalam menyelesaikan masalah yang terdapat pada proses absensi secara manual. Dengan mengintegrasi fitur QR Code pada sistem absensi berbasis web dapat menunjang terwujudnya absensi perkuliahan yang optimal dalam pengolahan data, mudah digunakan serta mengurangi waktu pengambilan absensi di kelas.

Metode penelitian yang digunakan dalam dari awal hingga akhir pembangunan perangkat lunak bagian modul absensi ini adalah melakukan studi pustaka, wawancara langsung pengelola pengembangan Sistem Informasi Mahasiswa di Universitas Universal, dan melakukan analisis dan perancangan pada pendekatan model proses waterfall.

\section{Tinjauan Pustaka Dan Teori}

\subsection{Sistem Informasi Akademi}

Sistem Informasi Akademi merupakan suatu aplikasi yang dirancang/dikembangkan untuk membantu lembaga pendidikan dalam mengelola data-data yang bersifat akademi. Sistem informasi akademi terdiri dari beberapa modul/menu di antaranya modul referensi, modul penerimaan mahasiswa baru, modul guru dan pelajaran, modul jadwal dan kalender, modul kesiswaan, modul presensi/absensi, modul penilaian, modul kenaikan dan kelulusan, modul mutasi serta modul lainnya (Ahmar, 2012). Sistem Informasi Akademi merupakan sistem yang dipergunakan dalam mengelola data dan melakukan proses aktifitas akademi dimana yang 
menghubungkan antara siswa, guru, administarsi akademi, penilaian dan data atribut lainya (Jamaliah, 2011) (Sutabri, 2012). Sistem informasi akademi dapat ditarik benang simpulnya bahwa Sistem informasi akademi merupakan sistem berupa perangkat lunak dan/atau dibantu dengan perangkat keras yang menaungi setiap kegiatan serta proses yang terjadi didalam sebuah institusi pendidikan mulai dari kegiatan admistrasi akademi, proses belajar-mengajar sampai pada proses kelengkapan berkas dokumentasi, dan dana yang bisa saja muncul pada setiap kegiatan registrasi ataupun dalam kegiatan operasional yang bisa dilihat per kategori per hari/per minggu/per bulan.

\subsection{Absensi}

Absensi berarti "ketidakhadiran", namun dapat katakan suatu rekapitulasi terhadap kehadiran di tempat yang merupakan bagian aktifitas pelaporan yang ada dalam sebuah Lembaga/perkumpulan (Coreit, dkk, 2015). Pada umumnya bahwa jenis-jenis absensi berdasarkan penggunaannya dapat dikelompokan, seperti:

1) Absensi manual, yaitu absensi yang pendataan absensi kehadiran menggunakan pena untuk mencatat tanda tanggan peserta institusi yang hadir.

2) Absensi non-manual, yaitu absensi yang pendataan absensi kehadiran menggunakan alat yang sudah terkomputerisasi.

\subsection{Aplikasi Mobile}

Aplikasi mobile terdapat dua kata, yaitu aplikasi dan mobile, dimana aplikasi merupakan program tersedia digunakan yang dibuat untuk memproses suatu fungsi tertentu yang berfungsi pada penggunanya atau aplikasi lainnya yang terintegrasi, sedangkan mobile adalah alat bantu dalam peralihan dari satu tempat ke tempat yang lain. Jadi, aplikasi mobile adalah program yang tersedia dan terdapat fungsi tertentu yang dipasang pada alat bantu mobile (Siregar, dkk, 2016).

Aplikasi mobile merupakan perangkat lunak yang dipergunakan pada alat bantu mobile seperti smartphone. Aplikasi mobile merupakan perangkat lunak yang dapat diunduh kedalam perangkat mobile dengan tujuan untuk menambah fungsionalitas dari perangkat mobile. Aplikasi mobile dapat diunduh melalui seperti Google Playstore untuk sistem operasi android atau
iTunes untuk sistem operasi iOS (Irsan, 2015) (Safaat, 2012).

\subsection{Quick-Response Code (QR Code)}

Sistem QR Code terdiri dari encoder dan decoder. Encoder bertujuan untuk mengenkripsikan data/informasi, sementara decoder bertujuan untuk menerjemahkan $\mathrm{QR}$ Code ke dalam data/informasi. Deskripsi tersebut ditunjukkan pada Gambar 1, yaitu gambaran kerja QR code (Tiwari, 2017).

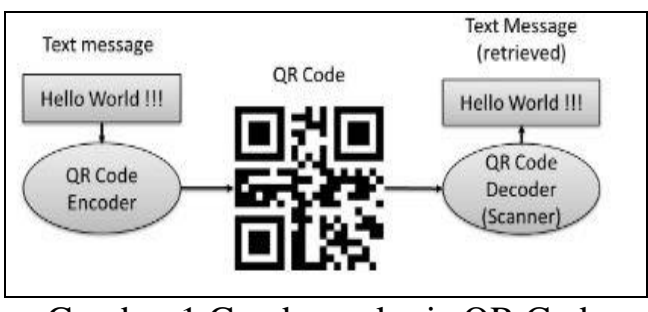

Gambar 1 Gambaran kerja QR Code

Gambar 1 menunjukkan gambaran kerja QR Code. Data/informasi yang berupa teks, Uniform Resource Locator (URL) ataupun data/informasi dalam bentuk lainnya akan di enkripsikan kedalam bentuk QR Code dan ketika ingin mengakses data/informasi yang sudah diubah kedalam bentuk QR Code hanya perlu melakukan pemindaian $\mathrm{QR}$ Code (decoder) yang akan mengubah QR Code kedalam bentuk data/informasi.

\section{Metodologi Penelitian}

Cara yang digunakan dalam proses penelitian dalam mendukung pencarian data, pembuatan perangkat lunak maupun data yang akan dibangun. Metodologi penelitian yang digunakan penulis dapat dikelompokkan menjadi beberapa tahapan, yaitu studi Pustaka, wawancara, analisis dan perancangan.

\subsection{Studi Pustaka}

Studi Pustaka atau penelitian kepustaakaan dengan mendapatkan informasi berhubungan dengan pengujian performa dengan cara mempelajari buku-buku dan artikel/paper bersumber dari jurnal-jurnal nasional maupun jurnla internasional yang berkaitan dalam membantu proses menyelesaikan penelitian ini.

\subsection{Wawancara}

Wawancara dengan metode dengan langsung melakukan tanya-jawab terhadap orang yang bersangkutan pada bagian pengelola 
Pengembangan Sistem Informasi Mahasiswa yang akan diteliti.

\subsection{Analisis dan Perancangan}

Pada tahap ini dimulai dengan menggunakan proses perangkat lunak yaitu model waterfall. Model waterfall merupakan salah satu dari model proses pada bagian prespektif.

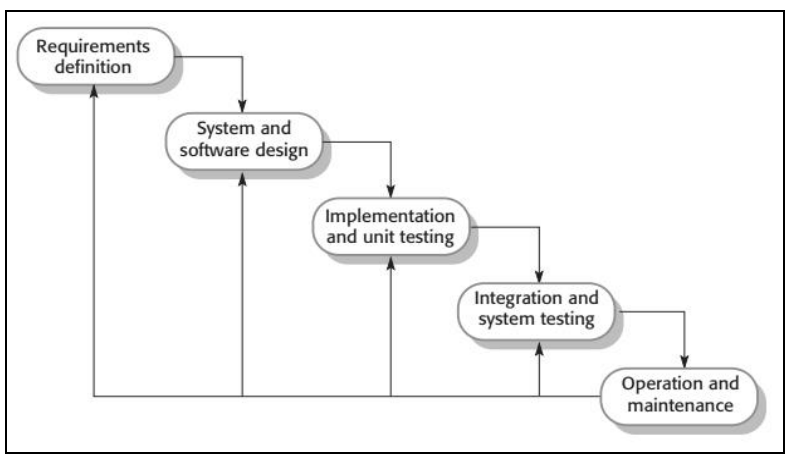

Gambar 2 Model Waterfall

Model waterfall terdiri dari lima tahap (Sommerville, 2016), yaitu:

(1.) Analisis dan menetapkan segala kebutuhan/persyaratan pada perangkat lunak yang akan dibangun.

(2.) Merancang/mendesain sesuai dengan hasil analisis dari no 1.

(3.) Penerapan coding, dan programmer menguji komponen yg dia rancang bangun.

(4.) Melakukan integrasi/menghubungkan antarkomponen, dan sekaligus melakukan pengujian sistem secara keseluruhan.

(5.) Mengoperasikan program yang selesai dibangun di lingkungan Client, dan melakukan perawatan pada perubahan/maintenance, seperti menyesuaikan pada perbaikan karena adaptasi dengan keadaan sebenarnya.

Pada tahap ini juga dilakukan pengumpulan data yang berhubungan dengan model database, relasi data, jenis, dan karakteristik data. Pemodelan perangkat lunak dibantu dengan Unified Modeling Language (UML). Analisis Desain akan disesuaikan dengan hasil yang didapatkan dari tahap analisis data. Perancangan sistem atau yang sering disebut dengan implementasi aplikasi menggunakan bahasa pemrograman Hypertext Prepocessor (PHP) untuk web based, dan Bahasa Pemrograman Java untuk mobile based.
4 Hasil dan Pembahasan

4.1 Use Case Diagram pada Modul Sistem Absensi

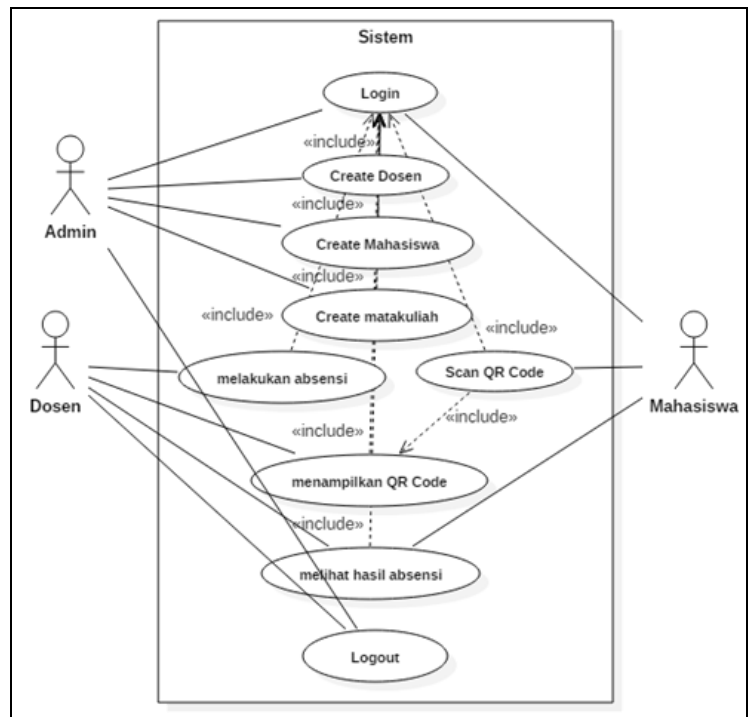

Gambar 3. Use Case Diagram

Gambar di atas menjelaskan alur sistem yang akan berjalan pada sistem absensi yang sedang dikembangkan, mulai dari login, melakukan absensi, melihat hasil absensi, dan menampilkan QR Code. Pada use case diagram di atas melibatkan beberapa aktor di antaranya dosen dan mahasiswa. Pemaparan dari aktoraktor yang dilibatkan dalam modul sistem absensi yang dibangun, yaitu:

Tabel 1. Pemaparan Aktor

\begin{tabular}{|c|c|c|}
\hline No & Aktor & Desripsi \\
\hline 1 & Admin & \begin{tabular}{lr}
\multicolumn{3}{l}{ Aktor dapat melakukan login } \\
kedalam sistem untuk \\
melakukan create data \\
dosen, mahasiswa dan \\
matakuliah
\end{tabular} \\
\hline 2 & Dosen & $\begin{array}{l}\text { Aktor dapat menjalankan } \\
\text { semua fitur yang tersedia } \\
\text { pada sistem absensi, mulai } \\
\text { dari login, melakukan } \\
\text { absensi mahasiswa, melihat } \\
\text { hasil absensi dan } \\
\text { menampilkan kode QR }\end{array}$ \\
\hline 3 & Mahasiswa & $\begin{array}{l}\text { Aktor login kedalam sistem } \\
\text { untuk melakukan proses } \\
\text { absensi dengan melakukan } \\
\text { scan kode QR dan melihat } \\
\text { hasil Absensi }\end{array}$ \\
\hline
\end{tabular}




\subsection{Activity Diagram untuk Login Sistem} Absensi

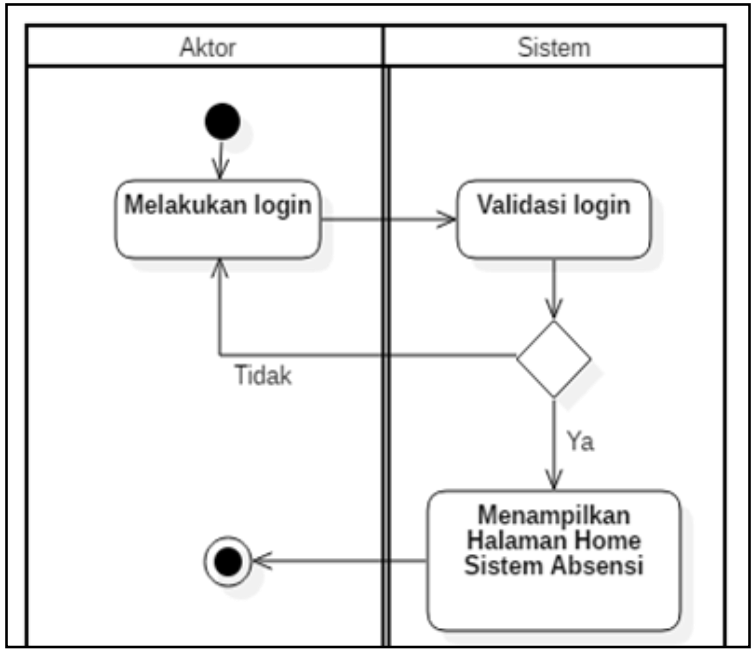

Gambar 4. Activity diagram untuk login

Gambar 4 ini merupakan proses login kedalam sistem absensi mahasiswa yang dilakukan oleh dosen dan mahasiswa. aktor akan memasukkan ID dan password akun kedalam sistem. sistem akan memvalidasi data akun aktor yang terdiri dari 2 kemungkinan terjadi yaitu:

(1.) Jika ID dan Password yang di-input dengan benar, maka tampilan sistem akan menuju ke tampilan Home modul sistem absensi.

(2.) Jika salah, maka sistem akan mengirim pesan bahwa ID atau Password yang dimasukkan salah

\subsection{Activity Diagram Create Dosen}

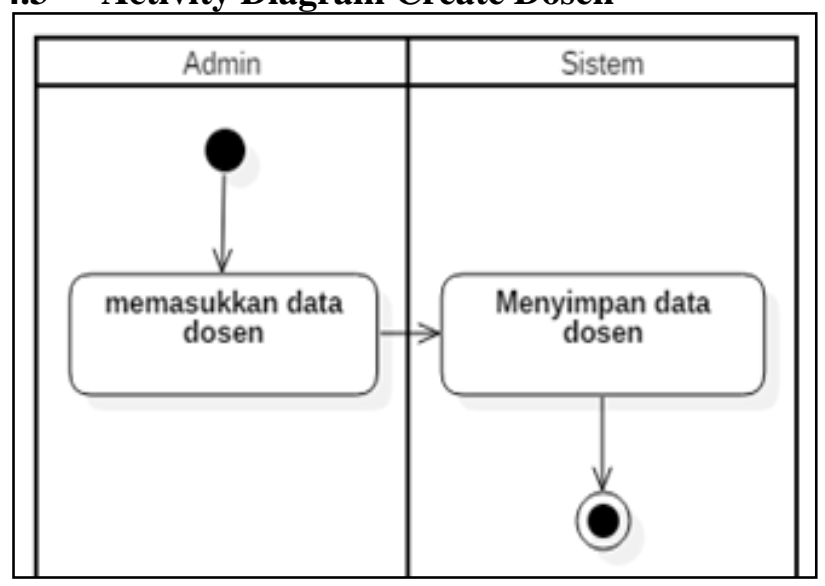

Gambar 5. Activity diagram untuk create data dosen

Activity diagram untuk create data dosen menggambarkan alur proses yang terjadi ketika admin akan melakukan input data dosen kedalam sistem. data yang di input oleh admin akan disimpan sistem kedalam tabel dosen pada sistem absensi.

\subsection{Activity Diagram untuk create}

Mahasiswa

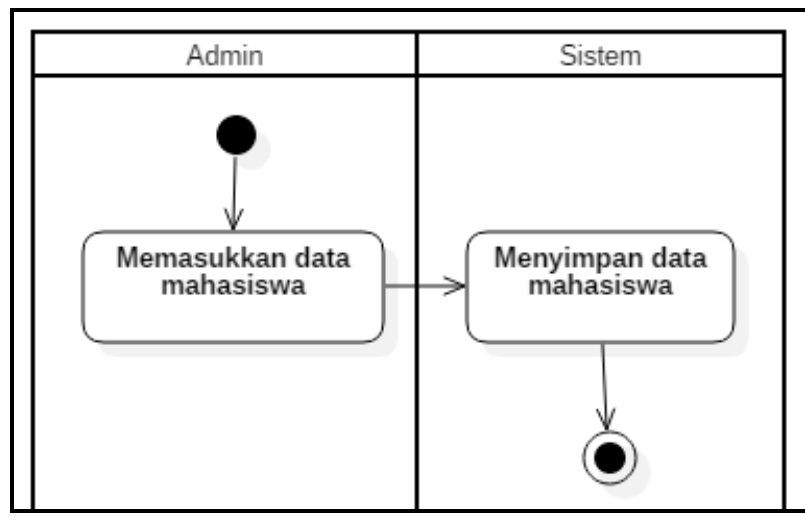

Gambar 6. Activity diagram untuk create data mahasiswa

Activity diagram untuk create mahasiswa menggambarkan alur proses yang terjadi ketika admin akan melakukan input data mahasiswa kedalam sistem. data yang di input oleh admin akan disimpan sistem kedalam tabel mahasiswa pada sistem absensi.

\subsection{Activity Diagram Untuk Create Data Matakuliah}

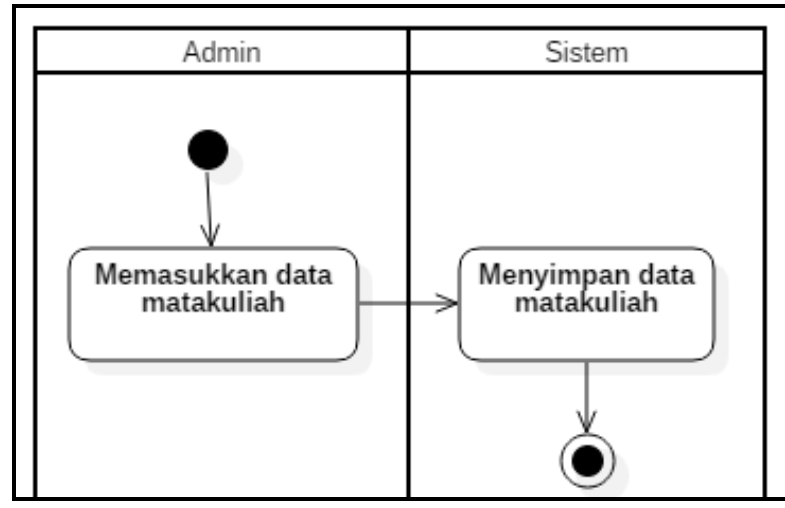

Gambar 7. Activity diagram untuk Create data matakuliah

Activity diagram untuk create data matakuliah menggambarkan alur proses yang terjadi ketika admin akan melakukan input data matakuliah kedalam sistem. data yang di input oleh admin akan disimpan sistem kedalam tabel matakuliah pada sistem absensi. 


\subsection{Activity Diagram Absensi}

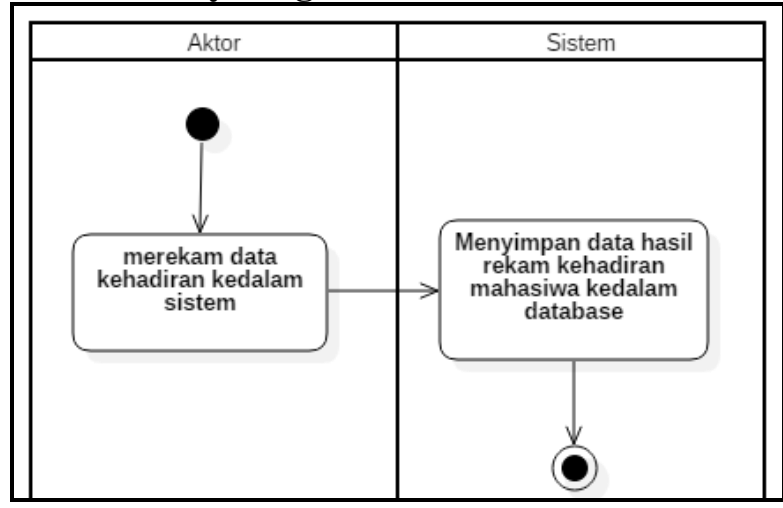

Gambar 8. Activity diagram melakukan absensi

Aktifitas aktor melakukan absensi yaitu dimana aktor merekam data kehadiran kedalam sistem melalui 2 cara yaitu:

(1.) Dosen merekam data kehadiran seluruh mahasiswa yang ada dikelas melalui website sistem absensi mahasiswa

(2.) Setiap mahasiswa yang ada dikelas merekam kehadirannya masingmasing degan melakukan scan QR Code melalui aplikasi mobile sistem absensi mahasiswa

Setelah melakukan rekam kehadiran mahasiswa maka sistem akan menyimpan data hasil rekam kehadiran tersebut kedalam database sistem.

\subsection{Activity Diagram Melihat Hasil Absensi}

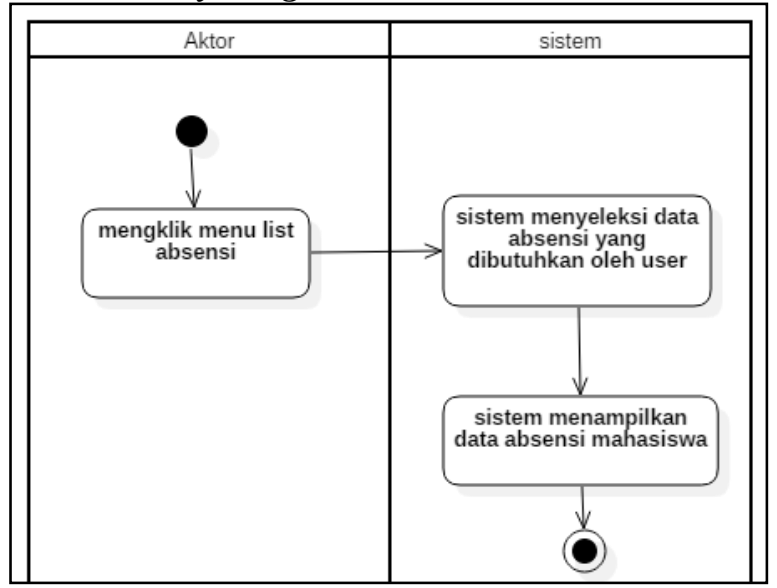

Gambar 9. Activity diagram melihat hasil absensi

Aktor dapat melihat hasil rekam kehadiran mahasiswa dengan mengklik menu list absensi. Sistem akan menyeleksi data absensi mahasiswa yang berada didalam kelas dosen pengampuh. Sistem akan menampilkan daftar absensi mulai dari pertemuan pertama sampai pertemuan terakhir.

\subsection{Activity Diagram Menampilkan QR Code}

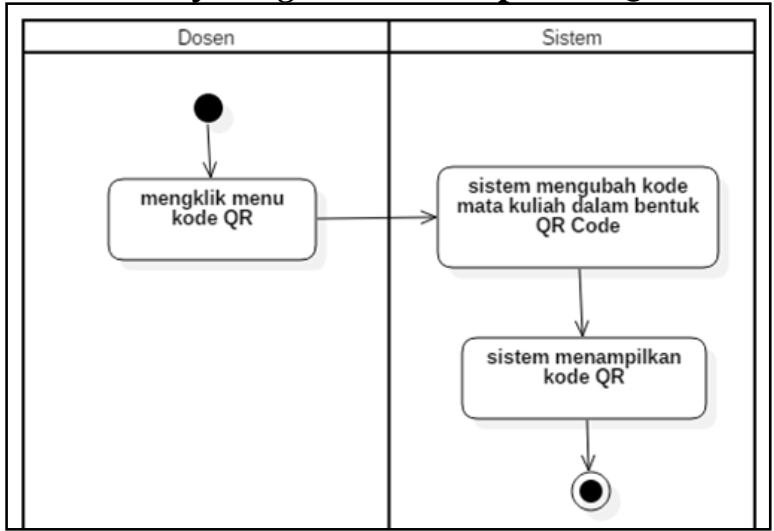

Gambar 10. Activity diagram menampilkan QR Code

Dosen mengklik menu QR Code untuk menampilkan kode QR. QR Code berfungsi sebagai media akses yang digunakan mahasiswa untuk melakukan absensi degan memindai kode QR menggunakan aplikasi sistem absesnsi. Sistem akan menggubah kode mata kuliah ke dalam bentuk QR Code lalu menampilkannya.

\subsection{Class Diagram yang Dirancang}

Class Diagram merupakan diagram yang menggambarkan interaksi yang terjadi antara class yang terdapat pada sistem yang sedang dibangun. Pada proses analisis ini terdapat class diagram yang dianalisis pada modul sistem absensi.

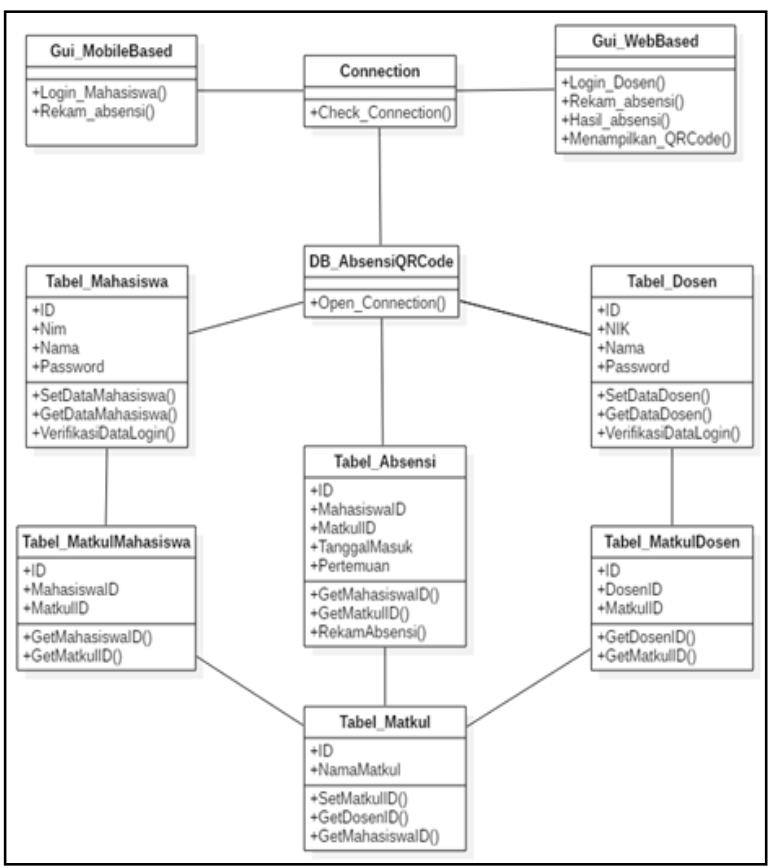


Gambar 11. Class diagram Sistem Absensi Mahasiswa

\subsection{Spesifikasi Kebutuhan Perangkat Lunak}

Perangkat lunak yang dipergunakan dalam membangun sistem absensi berbasis mobile dan web, terdiri dari:

(1.) Sistem Operasi Windows 10 Pro

(2.) Microsoft Visual Studio Code 1.39.2

(3.) XAMPP server 5.6.3

(4.) Android Studio 3.6.3

(5.) StarUML 3.0.2

(6.) Google Chrome

\subsection{Spesifikasi Kebutuhan Perangkat Keras}

Perangkat keras yang digunakan membangun modul sistem absensi berbasis mobile dan web adalah sebagai berikut:

(1.) Komputer/Laptop
(a.) Processor Intel ${ }^{\circledR}$ Core $^{\mathrm{TM}}$ i7- 3632QM @2.20GHz
(b.) Memory (RAM) 8 GB
(c.) Kapasitas Hardisk 700 GB
(d.) GPU AMD Radeon HD 7600M Series

(2.) Handphone
(a.) Model : Xiomi MI PLAY
(b.) Sistem Operasi: Android 8.1.0 (Oreo)
(c.) $\mathrm{CPU}$ : Octa-core Max $2.3 \mathrm{GHz}$
(d.) Memory (RAM) : 4 GB
(e.) Screen Size : $64 \mathrm{~mm} \mathrm{X} 134$ $\mathrm{mm}$

\subsection{Implementasi Pada Aplikasi Web Based}

Antarmuka sistem absensi mahasiswa web based ini terdiri dari beberapa tampilan di antaranya sebagai berikut:

\section{1) Antarmuka Login Untuk Dosen}

Antarmuka login untuk dosen merupakan tampilan awal yang akan muncul ketika user mengakses sistem absensi mahasiswa berbasis web.

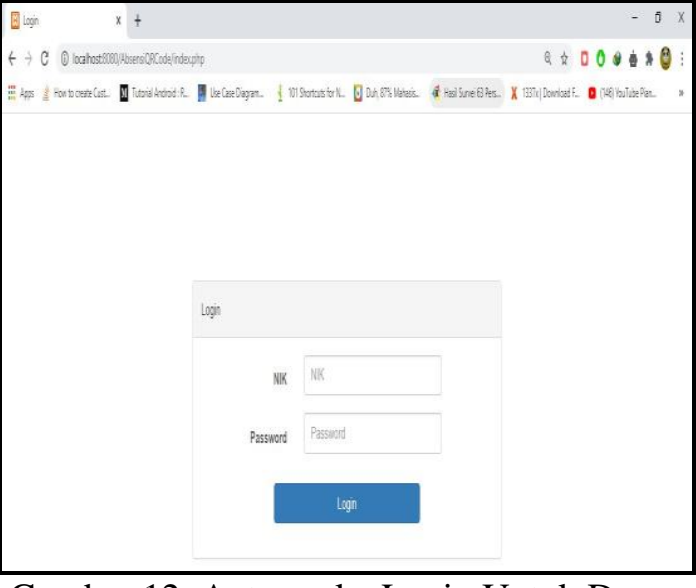

Gambar 12. Antarmuka Login Untuk Dosen

\section{2) Antarmuka Home}

Antarmuka menu home merupakan menu yang akan ditampilkan sistem setelah user berhasil melakukan login ke dalam sistem.

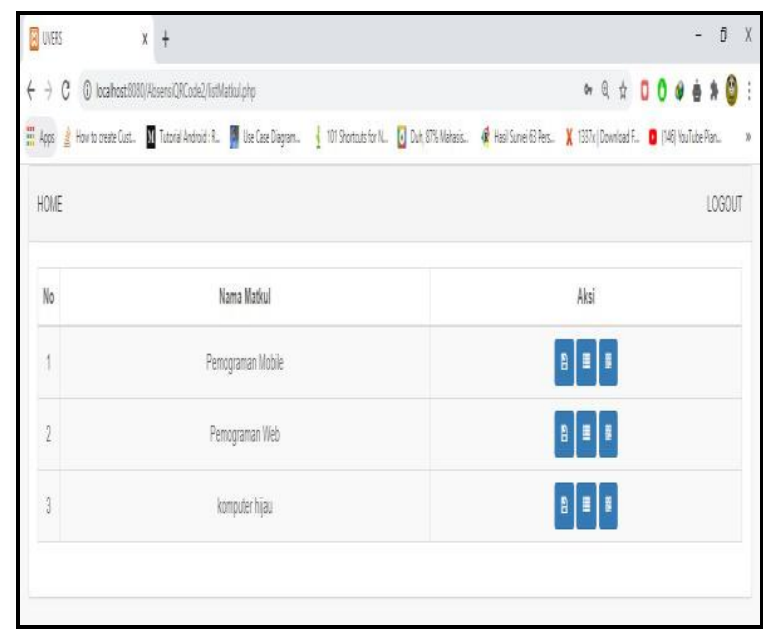

Gambar 13. Antarmuka Menu Home

\section{3) Antarmuka Rekam Absensi}

Antarmuka menu rekam absensi merupakan menu untuk merekam kehadiran mahasiswa.

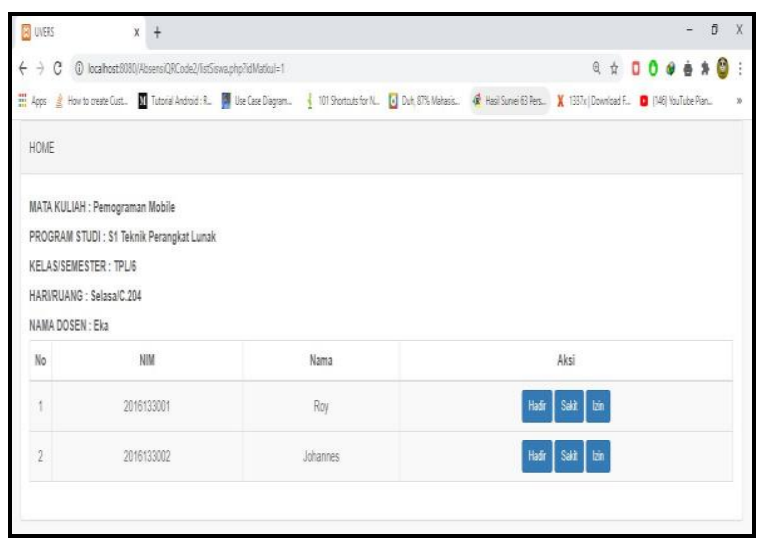

Gambar 14. Antarmuka Menu Rekam Absensi 


\section{4) Antarmuka Hasil Absensi}

Antarmuka menu hasil absensi merupakan menu untuk melihat hasil absensi seluruh mahasiswa yang menggambil mata kuliah

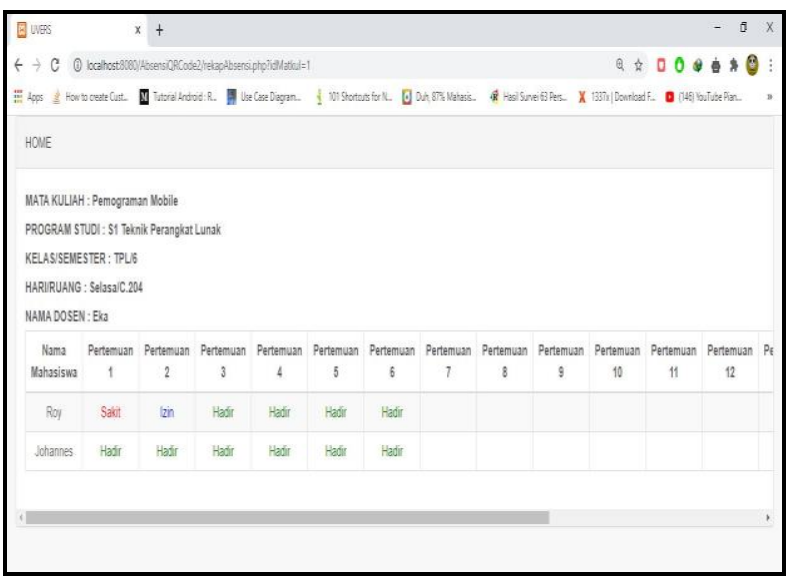

Gambar 15 Antarmuka Menu Hasil Absensi

\section{5) Antarmuka Tampilan QR Code}

Antarmuka menu QR Code merupakan menu untuk menampilkan kode QR yang akan dipindai mahasiswa sebagai akses untuk rekam kehadiran.

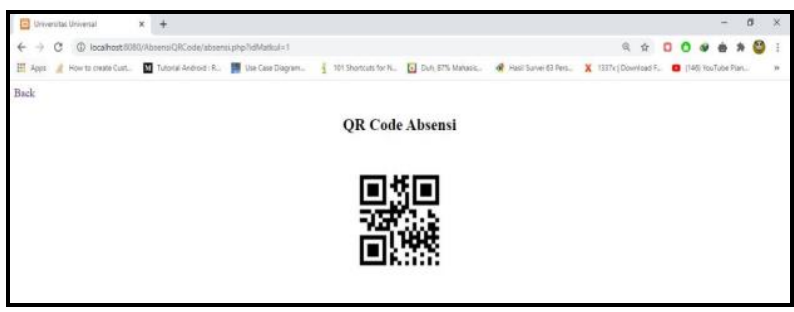

Gambar 16. Antarmuka Menu QR Code

\section{6) Antarmuka Admin}

Antarmuka menu Admin merupakan menu untuk membuat data baru dosen, mahasiswa dan matakuliah pada sistem Absensi.

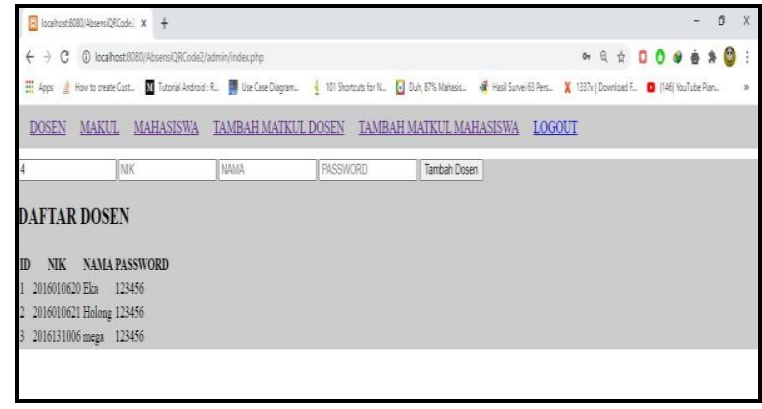

Gambar 17. Antarmuka Menu Admin

\subsection{Implementasi Pada Aplikasi Mobile}

Antarmuka sistem absensi mahasiswa web based ini terdiri dari beberapa tampilan di antaranya sebagai berikut:

\section{1) Antarmuka Login Mahasiswa}

Antarmuka login mahasiswa adalah tampilan awal yang akan ditampakkan ketika mahasiswa menelusuri sistem absensi mahasiswa berbasis mobile.

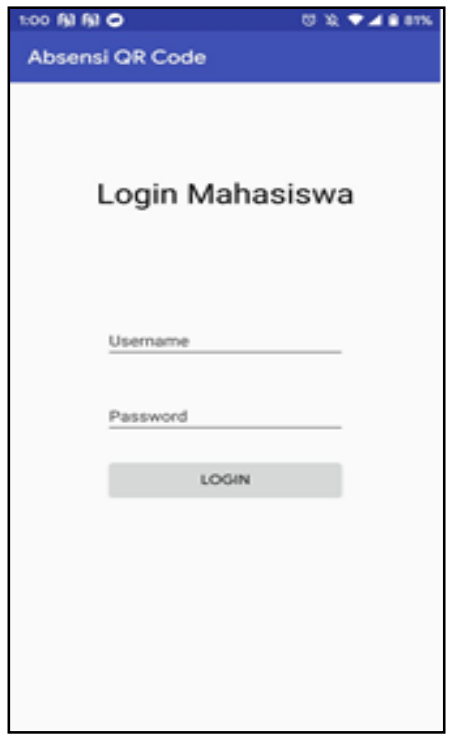

Gambar 18. Antarmuka Menu Login Mahasiswa

\section{2) Antarmuka Memindai QR Code}

Antarmuka memindai QR Code merupakan antar muka yang berfungsi untuk memindai $Q R$ Code untuk merekam absensi mahasiswa.

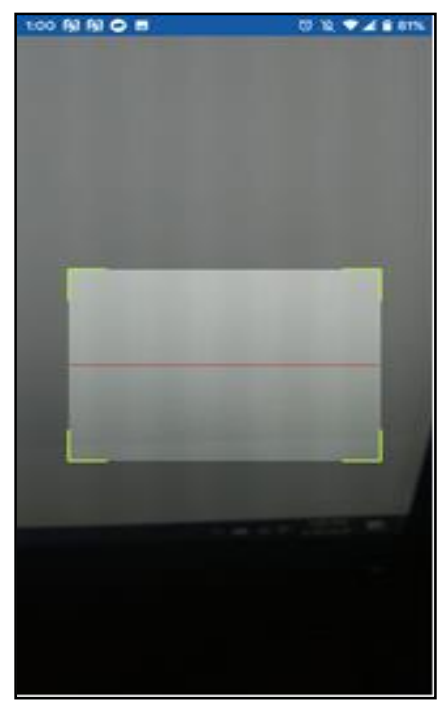

Gambar 19. Antarmuka Menu Memindai QR Code 


\section{Kesimpulan dan Saran}

Berdasarkan hasil perancangan dan pembangunan sistem absensi mahasiswa berbasis mobile dan web pada Universitas Universal di Kota Batam pada penelitian ini, dapat ditarik kesimpulan, yaitu:

a.Rancang bangun sistem Absensi berbasis mobile dan web dapat dirancang dan dibangun dengan menggunakan model waterfall dan analisis pemodelan UML

b. Fitur QR Code pada sistem absensi mahasiswa dapat digunakan sebagai media akses mahasiswa untuk melakukan absensi dikelas.

Saran yang dapat ditarik dari penelitian pada pengembangan modul sistem absensi mahasiswa berbasis mobile dan web pada Universitas Universal di Kota Batam adalah:

a. Sistem absensi mahasiswa ke depannya diharapkan dapat diintegrasikan ke dalam Sistem Informasi Akademi kampus sehingga data yang dibutuhkan absensi dapat ditarik langsung secara otomatis dari database akademi kampus tanpa harus dimasukkan secara manual.

b. Sistem absensi berbasis mobile dapat dipasang di berbagai sistem operasi smartphone seperti Android, iOS, dan Windows Phone

\section{Ucapan Terima Kasih}

Penulis berterima kasih kepada rekan-rekan mahasiswa dan Bapak/Ibu dosen dari Universitas Universal yang telah memberikan konsep cara pandang dan kemahiran yang sangat membantu penelitian ini, walaupun mungkin mereka tidak setuju dengan semua kesan/pendapat dari artikel ini.

\section{Referensi}

Ahmar, A. (2012). Panduan Sistem Informasi Akademik Sekolah Berbasis Web (L. Hakim (ed.)). Lokomedia.

Coreit, J., Setiawan, E. B., Kurniawan, B., Studi, P., Informatika, T., Indonesia, U. K., Studi, P.,
Elektro, T., \& Indonesia, U. K. (2015). Perancangan Sistem Absensi Kehadiran Perkuliahan dengan Menggunakan Radio Frequency Identification (RFId ). 1(2), 44-49.

Irsan, M. (2015). Rancang Bangun Aplikasi Mobile Notifikasi Berbasis Android Untuk Mendukung Kinerja Di Instansi Pemerintahan. Jurnal Penelitian Teknik Informatika, 1(1), 115-120. http://jurnal.untan.ac.id/index.php/justin/article/vi ew/9984/9752

Jamaliah. (2011). Sistem informasi akademik berbasis client server.

Nalintipwong, S., Tasarika, T., Ruksomya, C., Vittayakorn, S., \& Numnonda, T. (2019). No Title. 2019 IEEE 9th International Conference on Electronics Information and Emergency Communication (ICEIEC), 1-5. https://doi.org/10.1109/ICEIEC.2019.8784518

Onny, A. A. R., Danur, D., Piarsa, I. N., \& Sudana, A. A. K. O. (2016). Rancang Bangun Aplikasi Absensi Mahasiswa pada Platform Android. Jurnal Ilmiah Merpati (Menara Penelitian Akademika Teknologi Informasi), 4(1), 72-81.

Safaat, N. (2012). ANDROID : Pemrograman Aplikasi Mobile Smartphone dan Tablet PC Berbasis Android (Edisi Revisi). Informatika Bandung.

Siregar, M., Permana, I., Sistem, J., Fakultas, I., Dan, S., Uin, T., Riau, S., Soebrantas, J. H., \& Pekanbaru-Riau, P. (2016). Rancang Bangun Aplikasi Berbasis Mobile Untuk Navigasi Ke Alamat Pelanggan Tv Berbayar (Studi Kasus: Indovision Cabang Pekanbaru) 1. Jurnal Rekayasa Dan Manajemen Sistem Informasi, 2(1), 82-94. www.hostinger.co.id

Sommerville, I. (2016). Software Engineering (M. Horton (ed.); 10th ed.). Pearson Education Limited.

Sutabri, T. (2012). Analisa Sistem Informasi (2nd ed.). Andi Yogyakarta.

Tiwari, S. (2017). An introduction to QR code technology. Proceedings - 2016 15th International Conference on Information Technology, ICIT 2016, 1, 39-44. https://doi.org/10.1109/ICIT.2016.38

Zebua, T., \& Pritiwanto. (2017). Pembangunan Web Mobile Absensi Mahasiswa Pada Platform Android Yang Terintegrasi Dengan Website Utama Sistem Informasi Akademik (SIA) STMIK Budi Darma. Jurnal Teknik Informatika Unika St. Thomas (JTIUST), 2(1), 100-107. 